\title{
Assessment of Modern Banking Services to Achieve and Realization of E-Commerce and Its Impact on the Profitability of Banks Listed on the Tehran Stock Exchange
}

\author{
Sadeqh Mahmoodi ${ }^{1} \&$ Hossein Naderi $^{2}$ \\ ${ }^{1}$ Graduated Master of Accounting, Islamic Azad University (IAU), Ilam branch, Iran \\ ${ }^{2}$ Full-time faculty members of Islamic Azad University (IAU), Ilam branch, Department of Accounting, Iran \\ Correspondence: Hossein Naderi, Full-time faculty members of Islamic Azad University (IAU), Ilam branch, \\ Department of Accounting, Iran. E-mail: hossein.acc@gmail.com/m_morvarid93@yahoo.com
}

Received: June 17, 2016

Accepted: July 8, 2016

Online Published: July 21, 2016

doi:10.5539/mas.v10n9p263

URL: http://dx.doi.org/10.5539/mas.v10n9p263

\begin{abstract}
The aim of this study was to investigate new banking services in order to achieve and the realization of e-commerce and its impact on banks' profitability listed on the stock exchange. This study is an applied research and from the logic implementation is descriptive survey study and the relationship between variables is correlation. In this study, data collection is by using library and field method, according to research hypotheses simple two-variable linear regression model was used. In this study, panel data is used to estimate and analyze quantitative and analytical and descriptive models by using Spss software. Among 3,000 delegates, managers and employees eight banks listed on the Tehran Stock Exchange using cluster sampling of 300 randomly selected as a population, and has been done during the period 2014-2015.

The results of Pearson correlation coefficient between the variables of new services banking and e-commerce and profitability is equal to (0.144), which indicates that new services bank has positive impact significant on the Tehran Stock Exchange in order to fulfill ecommerce and profitability of listed banks, which means that a variety of modern banking services and increasing their use not only further caused the fulfill of e-commerce, but also increased the profitability of banks and has a direct impact on the profitability of them.
\end{abstract}

Keywords: e-banking, e-commerce, profitability, new banking services

\section{Introduction}

Amazing development of information technology and ICT and expanding it to the money markets and the World Bank, in addition to facilitating the services for customers of banks, revolutionize banking current methods. Electronic banking services are doing things that offered set of benefits to customers, in the banking system, services may offered by ATM, consultant, branches or via the internet and customers in fact are who use these services (Sheikhan, 2008, pp. 23-19).

Electronic banking is one of the most important technologies function in industry and services, particularly electronic commerce. Today, electronic banking has changed the traditional way banks function, in other words such as online banking, electronic banking development reduces the importance of the physical branch banks as well as changing in customer demand for offered services and products (Sheikhan, 2008, pp. 23-19).

Today, because of competitive business activities and the development of different aspects information technology remembered as an enabling factor. The main advantage of the use of information technology that creates value in the organization is increasing efficiency and effectiveness in the organization. However, due to poor infrastructure and limited provision of electronic banking services in our country, significant contribution cannot be attributed to the profitability and efficiency of the banks, as well as the profitability is the main objectives and form the basis of the measure Bank activities constitute that has a significant correlation with the performance of the activities and operations of banks. The efficiency of the financial system is evaluated according to the performance of the system. The performance of the banking system through the return to the shareholders and depositors is measured, according to the purpose of the banking system in community activities is, fundraising wandering and guiding them towards economic activity and ultimately earning money, however, 
profitability should be considered as a necessity, because it increasing the profitability of the development of the banking system (Sheikhan, 2008, pp. 23-19). In this study we review the previous studies in the field of e-banking and e-banking and analysis the impact of ecommerce on the profitability of listed banks.

\section{The Importance of the Subject and Purpose of This}

Bank as the lead institution for the money market, has the important role of the economy and therefore the development of the country. In Iran, the volume of money market is about three times the capital market and more than 90 percent of domestic liquidity is displaced in banks; therefore, scientific thinking, and combining the results of research and studies and benefit from the experiences of other countries in various fields, can help the development of banks in Iran. The banking industry is one of the industry's most affected by the developments of technologies related to information and communication, diversity and provide new services, such as banking machines and point of sale (POS), Automatic teller machine (ATM), credit card services, internet banking networks and... creating new money consuming ways and examining their effects on the cost structure of banks and their performance in terms of profitability are issues worthy of attention. Due to globalization, banks and financial institutions generally have stabilized its presence on the Internet and in general with various objectives in the field of electronics, In fact, e-banking will soon become an aggressive business policy and not an obligation of inaction, today one of the strategies necessary to keep the country growing trend in world development is to move towards continuous improvement and optimization of the system and the effective use of available capacity and resources mortal society, the creation of such a dynamic movement in organization requires continuous review of units and constant monitoring and improvement of methods. Electronic banking and electronic equipment by using tools such as the internet, wireless communication networks, ATM, telephone and mobile offered banking services and products that the products and services are part of the funds are monetary and financial system.

The development of e-banking as an application of ICT markets for money, has been severely affected the banking industry in different countries, including Iran. E-banking have created development in the past business practices and procedures and fulfill speed and saving time. Also according to the policy of privatization and implementation of Article 44 of the constitution with regard to the future competitive environment, condition for the survival of the banks is more efficiency and profitability which is why it is important to evaluate the profitability of the Iranian economy (Barati, 2011, p. 4).

\section{Research Hypothesis}

1) There is a significant impact between modern banking services in e-commerce fulfillment and profitability of banks listed on the stock exchange.

2) There is a significant impact between provide mobile banking services in e-commerce fulfillment and profitability of the banks listed on the stock exchange.

3) There is a significant impact between International card services in e-commerce fulfillment and profitability of banks listed on the stock exchange.

4) There is a significant impact between the provision of Internet services in e-commerce fulfillment and profitability of the banks listed on the stock changes.

5) There is a significant impact between International telephone banking services in e-commerce fulfillment and profitability of the banks listed on the stock exchange.

6) There is a significant impact between the provision of ATM services in e-commerce fulfillment and profitability of the banks listed on the stock exchange.

7) There is a significant impact between Car service point of sale (POS) in e-commerce fulfillment and profitability of banks listed on the stock exchange.

8) There is a significant impact between International System FAQ services in e-commerce fulfillment and profitability of the banks listed on the stock exchange.

\section{Review of Literature}

Becchalli (2003), in his research showed that various categories of IT has ventures heterogeneous effects on the performance of the banks, so that investment has a positive effect in services, while investment in hardware and software have a negative effect on the profitability of banks.

Holden \& El-bannany (2004), in his study examines the impact of installing automated teller machines (ATM) to reduce labor costs and the results showed that the number of ATM machines (ATM) installed by the banks has 
positive impact on the profitability of banks by reducing the cost labor and reduce transaction costs.

Kozak (2005) examined the association between the uses of information technology on the profitability of banks, The results showed that electronic banking services in the short term has negative effect on the profitability of banks that the negative effects is the cause of investment banks in the field of infrastructure and staff training, but in the long run, these services will have a positive effect on the profitability of banks.

China \& colleagues (2009) studied the research entitled "The Impact of a plurality of ATM (ATM) on cost efficiency: in Taiwan" the results showed that the use of ATM has been able to reduce costs and by reducing costs, banks have been able to achieve higher performance levels.

Hisar campus (2008), in their study concluded that the profitability of electronic banking has been a gradual process and points out that internet banking and electronic distribution channels by adding a trickle of international banks to sectors of society and will lead to bank profitability.

Sana Haider Sumra et al. (2011) evaluating the impact of online banking with profitability aims to explore the relationship of internet banking through the website with Pakistan profitability in commercial banks. The results suggest a positive effect of Internet banking with the bank's profitability and size as the control variable has impact on the relationship between Internet Banking and profitability and medium-sized banks have more impact.

Ceylan Onay \& Emre Ozsoz (2012) in a study on 18 bank branches in Turkey conducted, the impact on profitability of banks online banking, by using panel data model, the results showe that the adoption of Internet banking has positive impact on profitability, the level of deposits and loans in each branch. But while increasing the competition it will have negative impact on profitability.

Husni Ali Khrawish \& Noor Mousa Al-Sa'di (2013) study the impact of e-banking in Jordan focused on the profitability of banks. The result of this research showed that there is no relationship between e-banking and banking profitability in terms of return of assets and return on equity.

\section{Research Method}

This research is descriptive research and from the logic implementation is descriptive survey study and the relationship between variables is correlational. The research methodology is causative (through the use of library resources and field) and implementation is deductive-inductive. In this study, panel data is used to estimate and analyze quantitative and analytical and descriptive models by using Spss software. In this study, executives and employees of eight listed bank in stock exchange which are 3,000 were selected as the population of the study. Data for the study has done by using field method and by two standard questionnaires electronic banking and productivity questionnaire.

Cronbach's alpha for the questionnaire labor productivity Hersey and Goldsmith presented in the following table:

Table 1. Cronbach alpha labor productivity

\begin{tabular}{ll}
\hline before & Related question \\
\hline Ability & 0.69 \\
Understanding & 0.82 \\
Organizational support & 0.77 \\
Motivation & 0.66 \\
Feedback & 0.74 \\
Credit & 0.77 \\
Compatibility & 0.76 \\
The entire questionnaire & 0.75 \\
\hline
\end{tabular}

In this study, the dimensions of ability, understanding, organizational support and motivation are used as factors in the profitability of the banking system. The productivity questionnaire in this study is used by combination of questionnaires of electronic banking which Cronbach's alpha coefficient is equal to (0.86).

The questionnaire used in this study is to examine the relationship between modern methods of electronic banking through e-commerce platform and the profitability of listed banks which combines efficiency with Hersey and Goldsmith used a questionnaire consisted of 40 questions separated in table 2. 
Table 2. Separate questionnaire based on variables

\begin{tabular}{ll}
\hline Before & Related question \\
\hline E-commerce and profitability & $1-12$ \\
mobile banking & $13-16$ \\
Card Services & $17-20$ \\
Internet banking & $21-24$ \\
TelePhone Bank & $25-28$ \\
POS & $29-32$ \\
ATM & $33-36$ \\
System FAQ & $37-40$ \\
\hline
\end{tabular}

The expert's estimation was positive about its validity, and thus it can be expected that the questionnaire used in the study have sufficient content.

To assess the reliability of questionnaires, Cronbach's alpha coefficient was used. One of the methods for calculating reliability is Cronbach's alpha coefficient which is 0.86 for this study.

\section{Hypothesis Testing and Used Statistical Methods}

The correlation coefficient between the variables of modern banking services and e-commerce fulfillment and profitability is $r=0.441$, and coefficient of determination calculated $R 2=0.19$. The coefficient of determination represents the amount of variance in the dependent variable that is explained by the independent variable. Here coefficient of determination is 0.19 , indicates that the variable modern banking services is explained 0.19 of variance (change) and ecommerce variables profitability.

The sig in the following table specifies the significance of the model. As it is shown the dependent variable $\mathrm{F}$ for e-commerce and profitability is equal to 71.822 with a significance level of 0.000 , which is significantly lower because the model is significant and is equal to 0.50 .

Table 3. Summary of regression model of first hypothesis

\begin{tabular}{lllll}
\hline levels & R & R2 & F & significant level F \\
\hline E-commerce and profitability & 0.441 & 0.19 & 71.822 & 0.000 \\
\hline
\end{tabular}

Note. Independent variables: modern banking services.

Here the beta for modern banking services in relation to e-commerce and profitability variable is equal to 0.441 .

Table 4. Coefficients of the variables included in the regression of first hypothesis

Coefficients $^{\mathrm{a}}$

\begin{tabular}{|c|c|c|c|c|c|}
\hline \multirow{2}{*}{ Model } & \multicolumn{2}{|c|}{ Unstandardized Coefficients } & \multirow{2}{*}{$\begin{array}{l}\text { Standardized Coefficients } \\
\text { Beta }\end{array}$} & \multirow{2}{*}{$\mathrm{t}$} & \multirow{2}{*}{ Sig. } \\
\hline & $\mathrm{B}$ & Std. Error & & & \\
\hline (Constant) & 2.296 & .163 & & 14.104 & .000 \\
\hline Khadamat Novin & .397 & .047 & .441 & 8.475 & .000 \\
\hline
\end{tabular}

Note. a. Dependent Variable: Sodavari_va_Tejara.

Coefficients $^{\mathrm{a}}$

\begin{tabular}{|c|c|c|c|c|c|}
\hline \multirow{2}{*}{ Model } & \multicolumn{2}{|c|}{ Unstandardized Coefficients } & \multirow{2}{*}{$\begin{array}{l}\text { Standardized Coefficients } \\
\text { Beta }\end{array}$} & \multirow{2}{*}{$\mathrm{t}$} & \multirow{2}{*}{ Sig. } \\
\hline & $\mathrm{B}$ & Std. Error & & & \\
\hline (Constant) & 2.296 & .163 & & 14.104 & .000 \\
\hline Khadamat_Novin & .397 & .047 & .441 & 8.475 & .000 \\
\hline
\end{tabular}

Note. a. Dependent Variable: Sodavari_va_Tejara; the regression equation: $\mathrm{Y}=0.397 \mathrm{X}+2.296$.

Second hypothesis: there is a significant impact between the provision of services in the fulfillment of e-commerce and profitability of the listed banks. 
Since the correlation matrix, significant level is lower than the error rate $(0.05)$.therefore, null hypothesis is rejected at the $95 \%$ confidence level and and first hypothesis is confirmed seen as an example of the correlation coefficient Pearson mobile banking and e-commerce and banking profitability between two variables is equal to 0.476 , which represents a significant and direct impact between them.

Here coefficient of determination is 0.22 , indicates that variable of the banks mobile is explained 0.22 of variance (change) ecommerce variables and profitability.

The sig in the following table specifies the significance of the model. As it is known as the dependent variable $\mathrm{F}$ for e-commerce and profitability is equal to 87.281 with a significance level of 0.000 , because significant level is lower than or equal to 0.05 , the model is significant.

Table 5. Summary of regression model of second hypothesis

\begin{tabular}{lllll}
\hline levels & $\mathrm{R}$ & $\mathrm{R} 2$ & $\mathrm{~F}$ & significant level F \\
\hline E-commerce and profitability & 0.476 & 0.22 & 87.271 & 0.000 \\
\hline
\end{tabular}

Note. Independent variable of the mobile banks.

Here the beta for mobile banking and e-commerce profitability associated with the variable is equal to 0.467 .

Table 6. Coefficients of the variables included in the regression equation of the second hypothesis Coefficients $^{\mathrm{a}}$

\begin{tabular}{|c|c|c|c|c|c|}
\hline \multirow{2}{*}{ Model } & \multicolumn{2}{|c|}{ Unstandardized Coefficients } & \multirow{2}{*}{$\begin{array}{l}\text { Standardized Coefficients } \\
\text { Beta }\end{array}$} & \multirow[b]{2}{*}{$\mathrm{t}$} & \multirow{2}{*}{ Sig. } \\
\hline & B & Std. Error & & & \\
\hline (Constant) & 2.665 & .109 & & 24.353 & .000 \\
\hline Hamrah_Bank & .289 & .031 & .476 & 9.342 & .000 \\
\hline
\end{tabular}

Note. a. Dependent Variable: Sodavari_va_Tejarat; the regression equation: $\mathrm{Y}=0.289 \mathrm{X}+2.665$.

The third hypothesis: there is a significant impact between the card services in e-commerce fulfillment and profitability of the banks listed in the stock exchange.

As you can see an example of Pearson correlation coefficient between the two variables, card services and e-commerce and banking profitability is equal to 0.115 , which represents a significant and direct impact between them.

Here coefficient of determination is 0.01 , indicates that the card service variable is explained 0.01 of variance (change) ecommerce and profitability variables.

Sig value in the table (4-19), determines the significance of the model. As it is shown amount of $F$ for the dependent variable and profitability of e-commerce is equal to 4.025 with a significance level of 0.000 , which the significantly level is lower than or equal to 0.05 the model is significant.

Table 7. Summary of regression model of third hypothesis

\begin{tabular}{lllll}
\hline levels & $\mathrm{R}$ & $\mathrm{R} 2$ & $\mathrm{~F}$ & significant level F \\
\hline E-commerce and profitability & 0.155 & 0.01 & 4.025 & 0.046 \\
\hline
\end{tabular}

Here the beta for card services in relation to e-commerce and profitability variable is equal to 0.115 .

Table 8. Coefficients of the variables included in the regression equation of third hypothesis

Coefficients $^{\mathrm{a}}$

\begin{tabular}{|c|c|c|c|c|c|}
\hline \multirow{2}{*}{ Model } & \multicolumn{2}{|c|}{ Unstandardized Coefficients } & \multirow{2}{*}{$\begin{array}{l}\text { Standardized Coefficients } \\
\text { Beta }\end{array}$} & \multirow{2}{*}{$\mathrm{t}$} & \multirow{2}{*}{ Sig. } \\
\hline & B & Std. Error & & & \\
\hline (Constant) & 3.418 & .123 & & 27.853 & .000 \\
\hline${ }^{1}$ Khadamat_Karti & .070 & .035 & .115 & 2.006 & .046 \\
\hline
\end{tabular}


Note. a. Dependent Variable: Sodavari_va_Tejarat; the regression equation: $\mathrm{Y}=0.070 \mathrm{X}+3.418$.

Fourth research hypothesis: there is a significant impact between the internet banking service in fulfill of e-commerce and profitability of listed banks.

Since in the correlation matrix, significant level is lower than the error rate $(0.05)$, therefore, null hypothesis is rejected at the $95 \%$ confidence level and first hypothesis is confirmed and seen as an example the correlation coefficient Pearson between two variables mobile banking and e-commerce and banking profitability, is equal to 0.474, which represents a significant and direct impact between them.

Here coefficient of determination is 0.22 , indicates that internet banking variable is explained 0.22 of variance (change) ecommerce and profitability variables.

The sig in the following table specifies the significance of the model. As it is known the dependent variable $\mathrm{F}$ for e-commerce and profitability is equal to 86.399 with a significance level of 0.000 , because the significant level is lower than or equal to 0.05 the model is significant.

Table 9. Summary of regression model of forth hypothesis

\begin{tabular}{lllll}
\hline levels & $\mathrm{R}$ & $\mathrm{R} 2$ & $\mathrm{~F}$ & significant level F \\
\hline E-commerce and profitability & 0.474 & 0.22 & 6.399 & 0.000 \\
\hline
\end{tabular}

Here the beta for internet banking in relation to e-commerce and profitability variable is equal to 0.474 .

Table 10. Coefficients of the variables included in the regression equation of forth hypothesis

\begin{tabular}{|c|c|c|c|c|c|}
\hline \multirow{2}{*}{ Model } & \multicolumn{2}{|c|}{ Unstandardized Coefficients } & \multirow{2}{*}{$\begin{array}{l}\text { Standardized Coefficients } \\
\text { Beta }\end{array}$} & \multirow{2}{*}{$\mathrm{T}$} & \multirow{2}{*}{ Sig. } \\
\hline & $\mathrm{B}$ & Std. Error & & & \\
\hline (Constant) & 2.655 & .111 & & 23.916 & .000 \\
\hline${ }^{1}$ Internet Bank & .291 & .031 & .474 & 9.295 & .000 \\
\hline
\end{tabular}

Note. a. Dependent Variable: Sodavari_va_Tejarat; the regression equation: $\mathrm{Y}=0.291 \mathrm{X}+2.655$.

The fifth hypothesis: There is a significant impact between International telephone banking services in e-commerce fulfillment and profitability of the banks listed on the stock exchange.

Since in the correlation matrix, significant level is lower than the error rate $(0.05)$, therefore, null hypothesis is rejected at the $95 \%$ confidence level and first hypothesis is confirmed and seen as an example the correlation coefficient Pearson between two variables internet banking and e-commerce and banking profitability, is equal 0.116, which represents a significant and direct impact between them.

Here coefficient of determination is 0.01 , indicates that mobile banking variable is explained 0.01 of variance (change) ecommerce and profitability variables.

The sig in the following table specifies the significance of the model. As it is known the dependent variable $\mathrm{F}$ for e-commerce and profitability is equal to 4.069 with a significance level of 0.045 , because the significant level is lower than or equal to 0.05 the model is significant.

Table 11. Summary of regression model of fifth hypothesis

\begin{tabular}{lllll}
\hline levels & $\mathrm{R}$ & $\mathrm{R} 2$ & $\mathrm{~F}$ & significant level F \\
\hline E-commerce and profitability & 0.166 & 0.01 & 4.069 & 0.045 \\
\hline
\end{tabular}

Here the beta for mobile banking in relation to e-commerce and profitability variable is equal to 0.116 . 
Table 12. Coefficients of the variables included in the regression equation of fifth hypothesis

Coefficients $^{\mathrm{a}}$

\begin{tabular}{|c|c|c|c|c|c|}
\hline \multirow[b]{2}{*}{ Model } & \multicolumn{2}{|c|}{ Unstandardized Coefficients } & \multirow{2}{*}{$\begin{array}{l}\text { Standardized Coefficients } \\
\text { Beta }\end{array}$} & \multirow{2}{*}{$\mathrm{t}$} & \multirow{2}{*}{ Sig. } \\
\hline & $\mathrm{B}$ & Std. Error & & & \\
\hline (Constant) & 3.413 & .124 & & 27.480 & .000 \\
\hline${ }^{1}$ Telephone Bank & .071 & .035 & .116 & 2.017 & .045 \\
\hline
\end{tabular}

Note. a. Dependent Variable: Sodavari_va_Tejarat; the regression equation: $\mathrm{Y}=0.071 \mathrm{X}+3.413$.

The sixth hypothesis: There is a significant impact between the provision of ATM services in e-commerce fulfillment and profitability of the banks listed on the stock exchange.

Since in the correlation matrix, significant level is lower than the error rate $(0.05)$, therefore, null hypothesis is rejected at the $95 \%$ confidence level and first hypothesis is confirmed and seen as an example the correlation coefficient Pearson between two variables ATM and e-commerce and banking profitability, is equal 0.144, which represents a significant and direct impact between them.

Table 13. The correlation matrix in the sixth hypothesis

\begin{tabular}{llll}
\hline independent variable & The dependent variable & The correlation coefficient & Significant level \\
\hline ATM & E-commerce and profitability & 0.144 & 0.012 \\
\hline
\end{tabular}

At this stage to assess the role of the independent variable (ATM) on the dependent variable (e-commerce and profitability) simple bivariate regression is used. A condition of using regression analysis with interval scale variables and another is the relationship between independent variables and the dependent variable. The correlation coefficient between variables ATM and e-commerce fulfillment and profitability is $r=0.144$, and coefficient of determination is $\mathrm{R} 2=0.02$. The coefficient of determination represents the amount of variance in the dependent variable that is explained by the independent variable.

Here coefficient of determination is 0.02 , indicates that ATM variable is explained 0.02 of variance (change) ecommerce and profitability variables.

The sig in the following table specifies the significance of the model. As it is known the dependent variable $\mathrm{F}$ for e-commerce and profitability is equal to 26.679 with a significance level of 0.012 , because the significant level is lower than or equal to 0.05 the model is significant.

Table 14. Summary of regression model of sixth hypothesis

\begin{tabular}{lllll}
\hline levels & $\mathrm{R}$ & $\mathrm{R} 2$ & $\mathrm{~F}$ & significant level F \\
\hline E-commerce and profitability & 0.144 & 0.02 & 26.679 & 0.012 \\
\hline
\end{tabular}

Here the beta for ATM in relation to e-commerce and profitability variable is equal to 0.144 .

Table 15. Coefficients of the variables included in the regression equation of sixth hypothesis

Coefficients $^{\mathrm{a}}$

\begin{tabular}{|c|c|c|c|c|c|}
\hline \multirow{2}{*}{ Model } & \multicolumn{2}{|c|}{ Unstandardized Coefficients } & \multirow{2}{*}{$\begin{array}{l}\text { Standardized Coefficients } \\
\text { Beta }\end{array}$} & \multirow[b]{2}{*}{$\mathrm{t}$} & \multirow[b]{2}{*}{ Sig. } \\
\hline & $\mathrm{B}$ & Std. Error & & & \\
\hline (Constant) & 3.349 & .126 & & 26.679 & .000 \\
\hline ATM & .090 & .036 & .144 & 2.520 & .012 \\
\hline
\end{tabular}

Note. a. Dependent Variable: Sodavari_va_Tejarat; the regression equation: $\mathrm{Y}=0.090 \mathrm{X}+3.349$.

The seventh hypothesis: There is a significant impact between Car service point of sale (POS) in e-commerce fulfillment and profitability of banks listed on the stock exchange.

Since in the correlation matrix, significant level is lower than the error rate (0.05), therefore, null hypothesis is rejected at the $95 \%$ confidence level and first hypothesis is confirmed and seen as an example the correlation 
coefficient Pearson between two variables POS and e-commerce and banking profitability, is equal 0.388 , which represents a significant and direct impact between them.

Table 16. The correlation matrix in the seventh hypothesis

\begin{tabular}{llll}
\hline independent variable & The dependent variable & The correlation coefficient & Significant level \\
\hline Machines selling point & E-commerce and profitability & 0.388 & 0.000 \\
\hline
\end{tabular}

Here coefficient of determination is 0.15 , indicates that POS variable is explained 0.02 of variance (change) ecommerce and profitability variables.

The sig in the following table specifies the significance of the model. As it is known the dependent variable $\mathrm{F}$ for e-commerce and profitability is equal to17.212 with a significance level of 0.000 , because the significant level is lower than or equal to 0.05 the model is significant.

Table 17. Summary of regression model of Seventh hypothesis

\begin{tabular}{lllll}
\hline levels & $\mathrm{R}$ & $\mathrm{R} 2$ & $\mathrm{~F}$ & significant level F \\
\hline E-commerce and profitability & 0.388 & 0.15 & 17.212 & 0.000 \\
\hline
\end{tabular}

Here the beta for $\mathrm{POS}$ in relation to e-commerce and profitability variable is equal to 0.388 .

Table 18. Coefficients of the variables included in the regression equation of seventh hypothesis

Coefficients $^{\mathrm{a}}$

\begin{tabular}{|c|c|c|c|c|c|}
\hline \multirow{2}{*}{ Model } & \multicolumn{2}{|c|}{ Unstandardized Coefficients } & \multirow{2}{*}{$\begin{array}{l}\text { Standardized Coefficients } \\
\text { Beta }\end{array}$} & \multirow[b]{2}{*}{$\mathrm{t}$} & \multirow{2}{*}{ Sig. } \\
\hline & $\mathrm{B}$ & Std. Error & & & \\
\hline (Constant) & 2.585 & .150 & & 17.212 & .000 \\
\hline${ }^{1}$ Pos & .315 & .043 & .388 & 7.262 & .000 \\
\hline
\end{tabular}

Note. a. Dependent Variable: Sodavari_va_Tejarat; the regression equation: $\mathrm{Y}=0.315 \mathrm{X}+2.585$.

The eighth hypothesis: There is a significant impact between International System FAQ services in e-commerce fulfillment and profitability of the banks listed on the stock exchange.

Since in the correlation matrix, significant level is lower than the error rate (0.05), therefore, null hypothesis is rejected at the $95 \%$ confidence level and first hypothesis is confirmed and seen as an example the correlation coefficient Pearson between two variables $\mathrm{Q}$ system and e-commerce and banking profitability, is equal 0.472 , which represents a significant and direct impact between them.

Here coefficient of determination is 0.15 , indicates that $\mathrm{Q}$ system variable is explained 0.22 of variance (change) ecommerce and profitability variables.

The sig in the following table specifies the significance of the model. As it is known the dependent variable $\mathrm{F}$ for e-commerce and profitability is equal to 85.433 with a significance level of 0.000 , because the significant level is lower than or equal to 0.05 the model is significant.

Table 19. Summary of regression model of eighth hypothesis

\begin{tabular}{lllll}
\hline levels & $\mathrm{R}$ & $\mathrm{R} 2$ & $\mathrm{~F}$ & significant level F \\
\hline E-commerce and profitability & 0.388 & 0.15 & 17.212 & 0.000 \\
\hline
\end{tabular}

Here the beta for Q system in relation to e-commerce and profitability variable is equal to 0.472 . 
Table 20. Coefficients of the variables included in the regression equation of eighth hypothesis

Coefficients $^{\mathrm{a}}$

\begin{tabular}{|c|c|c|c|c|c|}
\hline \multirow{2}{*}{ Model } & \multicolumn{2}{|c|}{ Unstandardized Coefficients } & \multirow{2}{*}{$\begin{array}{l}\text { Standardized Coefficients } \\
\text { Beta }\end{array}$} & \multirow{2}{*}{$\mathrm{T}$} & \multirow{2}{*}{ Sig. } \\
\hline & $\mathrm{B}$ & Std. Error & & & \\
\hline (Constant) & 2.671 & .110 & & 24.294 & .000 \\
\hline Porsesh Pasokh & 287 & .031 & .472 & 9.243 & .000 \\
\hline
\end{tabular}

Note. a. Dependent Variable: Sodavari_va_Tejarat; the regression equation: $\mathrm{Y}=0.287 \mathrm{X}+2.671$.

\section{Discussion and Conclusion}

In summary, the results of the hypothesis is as follows:

Table 21. The results of the research hypotheses

\begin{tabular}{|c|c|c|}
\hline Row & ypotheses & Result \\
\hline $\begin{array}{l}\text { First } \\
\text { hypothesis }\end{array}$ & $\begin{array}{l}\text { There is a significant impact between modern banking services in e-commerce } \\
\text { fulfillment and profitability of banks listed on the stock exchange }\end{array}$ & $\begin{array}{l}\mathrm{H}_{0} \\
\text { Reject }\end{array}$ \\
\hline Second & $\begin{array}{l}\text { There is a significant impact between provide mobile banking services in e-commerce } \\
\text { fulfillment and profitability of the banks listed on the stock exchange }\end{array}$ & $\begin{array}{l}\mathrm{H}_{0} \\
\text { Reject }\end{array}$ \\
\hline $\mathrm{a}$ & & \\
\hline $\begin{array}{l}\text { thira } \\
\text { hypoth }\end{array}$ & $\begin{array}{l}\text { ervices in e-commer } \\
\text { e }\end{array}$ & Reject \\
\hline rth & ervices in e & \\
\hline is & ill & ject \\
\hline & There is a si & $\mathrm{H}_{0}$ \\
\hline $\operatorname{six}$ & $\begin{array}{l}\text { ck exchange } \\
\text { es in e-commerce }\end{array}$ & \\
\hline hy & & \\
\hline $\begin{array}{l}\text { eighth } \\
\text { hypothes }\end{array}$ & (POS) in $\mathrm{e}$ & $\begin{array}{l}\mathrm{H}_{0} \\
\text { Reject }\end{array}$ \\
\hline hypo & $\begin{array}{l}\text { There is a significant impact between International System FAQ services in } \\
\text { e-commerce fulfillment and profitability of the banks listed on the stock exchange }\end{array}$ & $\begin{array}{l}\mathrm{H}_{0} \\
\text { Reject }\end{array}$ \\
\hline
\end{tabular}

\section{Suggestions}

- Proposals for the first hypothesis

Bank interest to deposits that will be opened especially via the electronic portal.

Opening bank deposits through e-banking.

Financial insurance of customers against any misuse of electronic banking in electronic banking.

Receiving facilities requests via electronic banking.

Buying and sell stocks and electronic securities via e-banking portal.

Offering financial analysis of electronic banking to customers.

- Proposals for the second hypothesis

Launch the geographical channel with high security for transactions and Internet transactions to raise increasing use of internet banking services.

Increased raising the amount of daily money transfer via the Internet bank.

- Proposals for the third hypothesis

Culturalization, complimentary self-service services, trust formation in order to use mobile banking services to save time and reduce unnecessary traffic.

- Proposals for the fourth hypothesis

Increase the safety factor transactions through telephone banking. 
Increase the services offered through telephone banking.

Ability to open an account and export cheque bank by phone.

- Proposals for the fifth hypothesis

Increase the amount of daily money transfer via card services.

Increase yields through credit cards.

Provide a single bank card to do all Bank card services.

Reduce the amount of fees when transferring funds between card and banking.

- Proposals for the sixth hypothesis

Providing free bills through ATM.

Increase according to the number of ATM machines in several areas.

Launched a new application for devices ATMs in order to speed up banking operations through these devices.

- Proposals for the seventh hypothesis

Ability to receive free accounts through the devices (POS).

The Creation of a single switch port and prevent the use of a separate tooling setup (POS) of the bank.

Increase in services provided by devices (POS) (payments, interbank fund transfer, etc.

- Proposals for the eighth hypothesis

Free financial and credit counseling to customers through questions and answers.

Learn how to use e-banking services through a system of questions and answers.

Ability to solve possible problems during financial transactions through the system of questions and answers.

\section{References}

Becali, E. (2003). Information technology and economic performance: Some evidence from EU banking industry. Retrieved from http://www.fana.org/stockholm/papers/itbanks-paper.pdf

Chavoshi, N. A. (2012). Present an impact assessment of corporate governance mechanisms on Earnings Management in Tehran Stock Exchange. Journal of Management Accounting Research, (12).

Diam, A. Z. (2006). Role of the electronic banking services on the profits of Jordanian bank. American Journal of Applied Sciences, 3(9), 1994-2004.

Financial Services Electronics. (2002). A New Method for the transformation of the financial sector. Monetary and Banking Research Institute.

Haji, M. F., Ghiasvand, A., Seyyed, S., \& Khshayar (2012). The impact on the profitability of selected banks private electronic banking mechanisms (Graduate student's thesis). Faculty of Economics and Accounting, Islamic Azad Tehran.

Hassanzadeh, A., \& Sadeghi, T. (2002). Effect of electronic banking on the development of the banking system, Economic Journal, (25 \& 26).

Hisar, C. (2008). The impact of Internet-Banking on Bank Profitability.

Holden, K., \& El-Bannany, M. (2004). Investment in information technology systems and other determinants of bank profitability in the UK. Applied Financial Economics, 14, 361-365.

Khrawis, A. H., \& Al-Sa'di, N. M. (2013). The Impact of E-Banking on Bank Profitability: Evidence from Jordan. Middle Eastern Finance and Economics ISSN, 1450-2889.

Onay, C., \& Ozsoz, E. (2012). The Impact of Internet-Banking on Brick and Mortar Branches (The Case of Turkey. Journal of Financial Services Research.

Qomi, V., Hasani, M., \& Ahsanfar, M. H. (2014). The effect of the development of electronic banking on the profitability of banks in Iran (Graduate student's thesis). University of Economic Sciences and consumer message.

Shateri, J., \& Emadzadeh, M. (2013). Check the spread of electronic banking on the profitability of Bank Sepah (Graduate student's thesis). University of Isfahan.

Sheikhan, S. (2009). Electronic banking strategies in Iran (6th Ed.). The Institute for Monetary Research in Iran. 
Siam, A. Z. (2006). Role of the electronic banking services on the profits of jourdanian banks. Amercan journal of applied sciences, 3(9), 1999-2004.

Sylwester, J., \& kozak (2005). The role of information technology in the profit and cost efficiency.

Tabriz, M. (2011). Infrastructure requirements in electronic banking. Information Technology, (123).

Takemura, T. (2003). Information system investment productivity and efficiency in Japanese banking industry.

The Central Bank of the Islamic Republic of Iran. (2014).

Unctad. (2010). Electronic Commerce and Development Report 2001-2008 unctad nations' publication.

\section{Copyrights}

Copyright for this article is retained by the author(s), with first publication rights granted to the journal.

This is an open-access article distributed under the terms and conditions of the Creative Commons Attribution license (http://creativecommons.org/licenses/by/3.0/). 